\title{
Community-based prevention of alcohol-related injuries: Possibilities and experiences
}

\author{
Marja Holmila and Katariina Warpenius \\ Alcohol and Drug Research Unit, National Institute for Health and Welfare (THL), Finland
}

\begin{abstract}
Aims: This paper discusses the possibilities of community-based prevention of alcohol-related injuries by summarizing the results from the Finnish Local Alcohol Policy (PAKKA).

Design: Quasi-experimental controlled pre-/post-intervention design.

Setting: The Finnish community-based prevention project PAKKA is described as an example of prevention that combines into one process the three necessary prevention elements: affecting the environment, grassroots enforcement of legislation, and education.
\end{abstract}

Participants: Two intervention areas and two matched control areas.

Measurements: Triangulation: purchase trials, school- and population survey and register data.

Results: There were reductions in alcohol availability among minors and among intoxicated customers, an increase in abstinence among underaged youth and some changes in attitudes and knowledge on age-limit control.

Conclusions: The results of PAKKA show that community-based action has the potential to produce results in all three prevention elements. One of the challenges is how to use community mobilization to target those who are less supportive of community interventions.

Alcohol's causal role in social and health problems, including injuries, is usually contributory, being only one of several factors increasing the likelihood of the incidence (Babor et al., 2oro; Cherpitel et al., 2009). Besides preventing injuries from taking place, prevention also aims to minimize the severity of physical harm caused-thus paying attention to the time before an accident, the time of the accident and the time after the accident. In each stage interventions can be directed to the person, the agent and the environment (Haddon, I980; Runyan, I998). The frame of reference of injury prevention has been summarized as three E's: engineering (safety of the environment and of products), enforcement (regulations and their enforcement) and education (influencing attitudes and behavior) (Lounamaa, Räback, \& Tiirikainen, 2009). The Finnish Local Alcohol Policy project (PAKKA) is described in this article as an example of such an approach.

In this paper, we look at injuries that have been caused by either unintended accidents or intentional violence. The difference between these two concepts is very clear from the moral point of view. Alcohol-related violence is a crime that can lead to criminal sanctions, while injuries that result from

Correspondence: Marja Holmila, P.O .Box 30, FI-0027I, Helsinki, Finland

Phone: +358 20610 7012

E-mail: marja.holmila@thl.fi

Financial support: National Institute for Health and Welfare; Finnish Ministry of Social Affairs and Health; Finnish Alcohol Monopoly; the cities of Hämeenlinna and Jyväskylä 
an accident are "no one's fault." In practice, the difference is not always so clear. Even if the injury has not been caused intentionally, it may result from punishable carelessness or negligence, perhaps caused by intoxication.

Community-based work in prevention offers many advantages. At a local level, it is possible to combine citizens' action with official policies. The action then combines the three E's into one process, affecting environment, grassroots enforcement of legislation, and people's knowledge and attitudes. Sustainable local action is, however, difficult without state-level support and legislation. It is also important that public opinion supports the methods used. Heavy drinkers rather than moderate drinkers, men rather than women, and single people rather than those who are married or cohabiting are most likely to oppose various alcohol control measures. These regularities are shown in studies from the United States, Canada, Norway and Finland (Giesbrecht, Ialomiteanu, Angling, \& Adlaf, 2007; Greenfeld, Ye, \& Giesbrecht, 2007; Holmila, Mustonen, Raitasalo, \& Österberg, 2009; Nordlund, 2007). The challenge is how to use community mobilization to target those who are less supportive of community interventions.

\section{Alcohol-related injuries and violence in Finland}

Use of alcohol, and especially heavy intoxication, is an important contributory factor behind injuries, violence and accidents. A substantial literature exists demonstrating a strong association between alcohol use and injury (Babor et al., 20I0; Cherpitel, 2007; Cherpitel et al., 2009). Individual as well as population-level studies also indicate a causal relationship between alcohol consumption and violence (Room \& Rossow, 200I). One possible causal explanation is that alcohol reduces inhibition and increases the sense of power for some individuals. Additionally, people tend to drink in social situations, some of which may be more likely to spawn a violence-related event than others (Borges, Macdonald, Cherpitel, Orozco, \& Peden, 2009). Injuries are the fourth most common single cause of death in Finland. Over 3,000 people die yearly in accidents and 800,000 are injured. Men have injuries more often than women (Tiirikainen,
2009). Alcohol has been found to be contributory in every third accidental death. Simultaneous use of alcohol and illegal drugs forms a considerable portion of deaths registered as drug-related (Salasuo, Vuori, Piispa, \& Hakkarainen, 2007).

A Finnish time-series study covering the time period 1950-2000 estimated that a one-liter increase in annual per capita consumption of pure alcohol corresponds to a $3 \%$ to $6 \%$ increase in the assault rate (Sirén, 2002). The annual number of assaults has been roughly paralleled by changes in alcohol consumption and economic affluence (National Research Institute of Legal Policy, 2009). There is no systematic recording of intoxication among injury patients in Finland, but some studies have looked into this. A two-year follow-up in a hospital in Kuusankoski, in southeastern Finland, showed that $24 \%$ to $25 \%$ of patients coming to the clinic had alcohol in their blood. During weekends, nearly half of the patients were intoxicated (Impinen, 2009; Nurmi-Lüthje et al., 2008). Violence was given as the reason for the injury in $7 \%$ of the cases. Among the victims of violence, $76 \%$ were men, and most of them were between 20 and 24 years old.

The strength of the relationship between violence and alcohol seems to be culturally dependent, being influenced among other things by patterns of drinking (Hadfield, 2009). Offenders in violent crimes are more likely to be young, particularly so in the case of violence between the males engaged in fights in streets and licensed premises. The rate of assaults is at its highest among 15-24-year-olds, and reduces with age (Kivivuori, 2008). The victims of violence are also mostly young (Lehti, Sirén, \& Hinkkanen, 2007).

Alcohol's presence in Finnish crime has led researchers to see the heavy-use and intoxicationoriented drinking culture as one of the reasons for the relatively high level of violence leading to death in Finland. The difference between Finland and other Scandinavian countries in the rate of homicides stems in particular from the high rate of lethal crimes among unemployed, marginalized Finnish men with alcohol dependence, to whom welfare policies have not given adequate support. In 2006 , the number of the homicides was 2.6 per 100,000 inhabitants, while the corresponding figures for Sweden and Denmark were I.I and I.2 respectively (Lehti \& Kivivouri, 2007).

The number of police-reported violent assaults is a commonly used indicator for rates of 
violence (e.g., Wallin, 2004). The recorded number of non-fatal assault offences is, however, influenced by the activity of the police, and call for some caution when examining the trends. It is known that a relatively small share of all violent crimes are reported; according to the 2006 study on victimization only $20 \%$ of violent acts were reported to the police. Public discussion may influence the degree of reporting. It has been noted that people's willingness to make a report on violence has grown in Finland, and reporting is now four times higher than in I980 (Lehti \& Kivivuori, 2007).

Drunkenness causes various harms to others than the intoxicated person. Those exposed to the harms caused by someone else's drinking report worry, stress, fear and reduced levels of well-being. According to the Finnish Drinking Survey of 2008, almost half of women and more than one-fifth of men reported having been afraid of intoxicated people in public places (Huhtanen \& Tigerstedt, 20IO). The harmful effects of others' drinking are perhaps worst and most continuous within the family or other close relationships (Klein \& Quinten, 2002; Peltoniemi, 2005; Velleman, 2002). Living with a person who abuses alcohol or other drugs can mean a great risk of injury due to neglect or violence for other family members, children included.

\section{The three E's in prevention}

Regulation of drinking behavior is among the most noteworthy methods of preventing injuries and violence. Preventing acute harms caused by intoxication can save lives and prevent various kinds of physical and social harm. Influencing intoxication is crucial. Young people are likely to experience acute harms even if they drink only during special occasions and have no symptoms of dependence or chronic illness due to drinking (Kraus, Baumeister, Pabst, \& Orth, 2009). The available methods can be classified according to the frame of reference of injury prevention into engineering, enforcement and education (“three E's").

\section{Engineering}

The acute harms experienced by young adults are linked with the situational characteristics of their drinking. Safety can be increased by improving the environments where people often party. For instance, in many cities or night-life centers both the police and individual bar owners have implemented surveillance systems, by installing closed-circuit television surveillance (Graham \& Bernards, 2009).
Communities have developed transportation options at night time: taxi services or late-night bus service. Adequate street lighting, police surveillance and traffic arrangements can be improved. In many Finnish localities NGOs have activated volunteers and parents to take walks in the streets of their city during Friday and Saturday nights, talking to the teenagers hanging out in the streets and trying to make sure they are safe. Studies on preventing problems related to alcohol consumption at licensed premises have shown that the restaurant's immediate environment, staff behavior and other specific environmental factors, such as queuing, level of noise or lack of space, can influence the level of risk for violence (Graham, Bernards, Osgood, \& Wells, 2006; Quigley, Leonard, \& Collins, 2003).

\section{Enforcement}

Most countries have legislation controlling the sale of intoxicants to people already intoxicated or otherwise vulnerable, for instance minors. Many countries also have legislation determining the minimum legal age for alcohol purchase. In Finland, the legal age for buying strong alcoholic drinks (more than $22 \%$ alcohol by volume) is 20 years, and is I8 for buying milder drinks. Most young people, however, start drinking earlier, usually before the age of I6 (Ahlström \& Karvonen, 20I0). As children are vulnerable to alcohol poisoning and accidents due to lack of knowledge and experience, enforcing this legislation-especially the ban on selling to those less than I8 years of age-is one important way of preventing injuries among young people.

The need to enforce these laws has been identified as a part of so-called situational prevention of harms and crimes. Responsible beverage service training, penalizing unlawful sales and surveillance are used as methods (Holmila \& Warpenius, 2009). Bartenders and waiters, who should control sales, are in a conflict situation, having a business interest in selling more. Enforcement of the law requires regular on-premise checks, an efficient liquor license system and public support. On the shop-floor level, good professional skills are needed in restraining disorder and aggression, and sometimes pacifying restless customers. Research results of on-premise interventions indicate that alcohol-associated problems can be reduced by combining environmental measures: bar staff training, written in-house policies and stricter enforce- 
ment of law (Casswell \& Zhang, I997; Wiggers et al., 200I).

Reviews of prevention efforts indicate that multi-component interventions increase the possibilities of reducing alcohol problems at licensed premises (Graham, 2000; Homel, McIlwain \& Carvolth, 200I). Some studies support the notion that community interventions targeting licensed premises can be effective in decreasing alcohol-related violence (Wallin, Norström, \& Andréasson, 2003; Wallin, 2004). Developing the restaurant environment can thus influence the amount of acute alcohol harms in licensed premises. These results are in line with the idea of situational crime prevention (Clark, I992).

\section{Education}

The acute harms experienced by young adults are linked with the drinking culture and values of masculinity and femininity. It is crucial to influence the drinking culture and the mechanisms of both individual and social controls of intoxication. Other cultural values than those specifically alcohol-related may also need reassessing: e.g., estimations of manhood, authority play among young males and men's self-image have been found to be linked with high levels of violence among young males (Ratele, Swart, \& Seedat, 2009).

Education can also be targeted to special risk groups. The most obvious group in this context is heavy-drinking people already risking their safety with intoxication. Screening and early intervention has been shown to be an efficient method of harm prevention. In Finland this has been studied mainly in open health care units and in occupational health care units (Seppä \& Aalto, 2009). Well-targeted early intervention in basic health care can be efficient in reducing alcohol-related harms (Aalto, Saksanen, \& Laine, 2000; Anderson, Laurant, Kanner, Wensing, \& Grol, 2004; Ballesteros, Duffy, Querejeta, Arino, \& GonzalezPinto, 2004; Bertholet, Daeppen, Wietlisbach, Fleming, \& Burnand, 2005; Kaner et al., 2007). Also, visits to emergency clinics have been widely studied and the use of mini-intervention has been tested. More information on the use of brief interventions in emergency clinics is needed (D'Onorio $\&$ Degutis, 2009). The problem is that the professionals often do not use these methods, and they may be poorly suited to the everyday life routines in these settings (Beich, Gannik \& Malterud, 2002; Bond \& Macdonald, 2009).

\section{Combining the three E's: Example of the PAKKA project}

In the tradition of community-based prevention, changes in the environment and various forms of education and information-giving are carried out simultaneously. Over recent years some systematic reviews have analyzed the results from studies testing the effectiveness of substance use prevention programs (Cuijpers, 2002; Flay, 2000; Foxcroft, Ireland, Lister-Sharp, Lowe, \& Breen, 2003; Komro \& Toomey, 2002; Tobler et al., 2000). All these reviews emphasize the importance of social environments in influencing behavior. In order to achieve sustained reduction in alcohol use and in related problems, communities need to create changes in the overall social and cultural environment. The most promising approaches are comprehensive multi-component approaches targeting high-risk drinking contexts, and community-level policy processes (Graham, 2000; Holder et al., 2002; Homel et al., 200I; Treno \& Holder, 2004; Wallin \& Gripenberg, 2005).

The Finnish community-based alcohol prevention program "Local Alcohol Policy" (PAKKA) was implemented during 2004-2007 in two Finnish regions and was a part of a national alcohol program led by the Ministry of Health and Social Affairs. The demonstration project systematically combined law enforcement, training in responsible beverage service and selling (RBS), media advocacy and broad co-operation between local authorities and alcohol entrepreneurs. The role of the researchers in planning and implementing the project can be characterized as participatory (Holmila, Holder, Andréasson, Baklien, \& Rossow, 2008). The underlying principle was that when the researchers shared with the actors the results of the evaluation study and heard their views and opinions at the various stages of the joint process, elements of a sustainable working model for local alcohol prevention and politics were being created.

PAKKA interventions consisted of several parallel, co-ordinated actions limiting the social and commercial availability of alcohol among adolescents and young adults, promoting responsible alcohol sales, changing drinking styles by reducing drunkenness, and influencing community attitudes and norms. The project continued the international tradition of research on community-based prevention of alcohol-related harms (Holder, 2000; Holmila, I997; Treno \& Holder, 2004; 
Wagenaar et al., 2000; Wallin, Norström, \& Andréasson, 2003).

The project was carried out in two Finnish regions: Jyväskylä (Intervention Area I), with I42,000 inhabitants, and Hämeenlinna (Intervention Area 2), with 90,000 inhabitants. Each area consists of an urban center with several smaller municipalities around it. Two regions with matching characteristics were chosen as comparison areas (with II6,000 and 99,000 inhabitants).

The project aimed to:

- create local structures and working methods for alcohol prevention

- change community attitudes and norms related to local alcohol control

- reduce underage drinking and availability of alcohol in retail stores and licensed premises, as well as from friends, siblings and parents

- reduce intoxication and related harms.

PAKKA focused on activities to strengthen the enforcement of existing alcohol regulations by combining the three E's as a multi-component community intervention. The Finnish alcohol law states that it is forbidden to sell, serve or supply alcoholic beverages to intoxicated or underage customers, and the responsibility for ensuring compliance lies with the entrepreneur. Thus the entrepreneur needs professional skills to control clients as well as vision and reasons to do so, sometimes against his or her short-term economic interests. In a multi-component approach the local authorities, markets and citizens were activated to find ways to better implement the law.

Law enforcement and sanctions were strengthened. Liquor licensing authorities increased monitoring visits in restaurants, pubs, bars and nightclubs to enforce the alcohol law. The joint discussions between the entrepreneurs, licensing authorities and project activists made monitoring more acceptable among the alcohol sellers. $R B S$ training programs consisted of a half-day drama-based education course providing information on alcohol legislation and practical working methods to implement it. The training provided information on alcohol law and advised servers on working methods. Law enforcement and RBS training were combined with opinion-building campaigns and community-wide media advocacy, creating public discussion on safety and drinking norms in licensed premises.

To strengthen the structures for co-operation, broad-based local steering groups consisting of municipal politicians and leading civil servants and key professionals were set up to provide general support for policy initiatives in both of the intervention regions. Separate task-oriented work groups that relied on existing community coalitions were also established. In the two intervention areas, awareness of problems associated with underage and heavy drinking was promoted. Local media advocacy created public discussion on safety and drinking norms. All the PAKKA campaigns, research results and events received considerable attention in the local media (Holmila, Warpenius, Warsell, Kesänen, \& Tamminen, 2009).

One major aim was to involve local customers, young adults and parents in the local activities. The campaigns were often planned together with students in local institutions. Young people organized events, carried out data collection independently or for researchers, and took part in seminars and writing local media articles. Project material was distributed via various channels, including to homes. Police and liquor licensing authorities were involved in campaigns for intensive control of alcohol sales to minors. A drama-based education program for parents emphasizing parental responsibilities in alcohol education was carried out in local schools. A completely new element in the local coalition was the active role of the owners and employees of local licensed premises and grocery shops.

One particular challenge was to find the right organizational place and structure for regional prevention work in the current Finnish reality. Even though centralized monopoly systems have historically been the backbone of alcohol control in the Nordic countries, there is also a rich and long tradition of seeking to reduce alcohol problems through local efforts in independent municipalities (Stenius, 2000; Warpenius \& Sutton, 2000). Finnish municipalities are nonetheless only modestly involved in alcohol control politics in comparison to other Nordic countries (Andersen, 2000). Municipalities are often too small, uninterested and powerless in relation to alcohol supply policies, or even in relation to implementation of the alcohol legislation. This, together with the dismantling of the centralized alcohol control system since the early I990s, has left the efforts of prevention policies in Finland rather powerless. There is an overwhelming feeling of lack of resources and lack of clarity as to the obligations of the different actors (Holmila, Warpenius, \& Tigerstedt, 2008). 


\section{Method}

The process and outcomes of the PAKKA project were evaluated in a quasi-experimental controlled pre-/post-intervention research setting with intervention and matched comparison areas before (2004) and after $(2006 / 2007)$ the interventions (Holmila \& Warpenius, 2007). The method of triangulation was used in the overall assessment of the project's impact. Various types of data and methods were used, and quantitative and qualitative research approaches and analyses were combined. Research articles on the distinct intervention components have also been published separately.

The impact of the age-limit component on availability of alcohol and public attitudes toward underage drinking was measured using pseudopatron purchase attempts in Area 2, population surveys and school-based surveys (Karlsson, Raitasalo \& Warpenius, 2008). In 2005/2006, 82\% of all Finnish pupils in comprehensive schools and $77 \%$ of students in high schools filled in the questionnaire, which covers living conditions, health and health-related behavior. Responses on two questions (minors' abstinence from alcohol and young people's assessments of how easy it is for a minor to buy beer or cider in one's own community) were used in the evaluation.

The licensed premises-component was measured with purchase trials in licensed onpremise venues in Intervention Area I and in the control area in 2004 and 2006 . A male actor pretended to be clearly under the influence of alcohol and tried to buy a pint of beer at the serving area. Every bar and nightclub was visited in the intervention and the control area (94 licensed premises in pre-intervention and Ioo premises in postintervention) (Warpenius, Holmila, \& Mustonen, 20I0).

Changes in alcohol-related violence were assessed using police records from the years 20042007. The numbers of violent assaults in the licensed premises or immediately outside them were examined. Data on weekend and night-time emergency cases were collected from the local hospitals for the years 2004-2006. Comparative studies have shown that among younger males, a considerable portion of weekend night-time emergency visits are alcohol-related. On the basis of this finding, a surrogate method has been found to provide a good estimate for assessing the communitylevel changes in alcohol-related harms (Young et al.,
2004). Finnish studies have also found that alcohol is drunk in greatest quantities during weekends, and deaths related to intoxication are also most common during weekends (Kantonen et al., 2006; Mäkelä, Martikainen, \& Nihtilä, 2005; NurmiLuthje et al., 2007). Data consisted of the number of male emergency unit patients aged I5-34 and 34-50 years who had arrived at the clinic between Friday and Saturday nights between гі:०० p.m. and 6:00 a.m. No information on possible alcohol involvement or the type of injury was collected. We were not able to get data on emergency cases from the control area for Intervention Area I.

\section{Results}

\section{The age-limit component}

According to the purchase trials, the age-limit control in the shops improved between the measuring points. In the baseline year of 2004 about half of the purchase attempts made by the pseudo-patrons succeeded. The refusal rate for the purchase trials in Intervention Area 2 was $52 \%$, whereas the corresponding figure in the control region was as low as $37 \%$ (Table I). In the 2006 follow-up the refusal rate in Area 2 had risen to $55 \%$. The refusal rate in the control region was, however, even higher, at $58 \%$. The fact that the changes in the intervention and the comparison areas were similar may be explained by the increased surveillance and spillover of PAKKA interventions to the comparison area.

In both regions, in both the baseline and the follow-up, the monopoly outlets had the strictest age-limit control. In 2006 only Io\% of the purchase attempts at monopoly outlets in Hämeenlinna were successful. The age-limit control improved between the measuring points for all other types of shops except for large supermarkets (Karlsson et al., 2008). Apart from type of outlet, the age and gender of the salesperson also had a bearing on the outcome of the purchase attempts. Younger checkout clerks tended to check IDs more seldom and also to sell more frequently to young people than did older clerks. In addition, male salespeople denied sales to young people more often than did females, at least at baseline. Also the time of purchase seems to have had some bearing on the success rate: more purchases succeeded between 4:00 p.m. and 6:00 p.m., which is the busiest time of the day, than after 6:0o p.m. 
Table 1

Age-limit measures in intervention and control areas in 2004 and 2006

\begin{tabular}{|c|c|c|c|c|}
\hline Measure & $\begin{array}{c}\text { Intervention I } \\
\%\end{array}$ & $\begin{array}{c}\text { Control I } \\
\%\end{array}$ & $\begin{array}{c}\text { Intervention } 2 \\
\%\end{array}$ & $\begin{array}{c}\text { Control } 2 \\
\%\end{array}$ \\
\hline \multicolumn{5}{|l|}{ Purchase refusals in retail stores } \\
\hline 2004 & $\ldots$ & $\ldots$ & 52 & 37 \\
\hline 2006 & $\ldots$ & $\ldots$ & 55 & 58 \\
\hline Change between 2004-2006 & & & ns & $+21 *$ \\
\hline \multicolumn{5}{|c|}{$\begin{array}{l}\text { Opinions of the youngsters: It is difficult to } \\
\text { buy alcohol }\end{array}$} \\
\hline 2004 & 32 & 33 & 36 & 36 \\
\hline 2006 & 45 & 48 & 49 & 56 \\
\hline Change between 2004-2006 & $+13 * * *$ & $+15 * * *$ & $+13 * * * *$ & $+20 * * *$ \\
\hline \multicolumn{5}{|c|}{$\begin{array}{l}\text { Population attitudes: It is inappropriate for a } \\
\text { 15-year old to have a drink in a family } \\
\text { celebration }\end{array}$} \\
\hline 2004 & 50 & 55 & 49 & 55 \\
\hline 2006 & 56 & 60 & 57 & 60 \\
\hline Change between 2004-2006 & $+6 *$ & ns & $+8 *$ & ns \\
\hline \multicolumn{5}{|l|}{ Abstinence, underage boys } \\
\hline 2004 & 35 & 26 & 28 & 31 \\
\hline 2006 & 45 & 36 & 38 & 43 \\
\hline Change between 2004-2006 & $+10 * * * *$ & $+10 * * *$ & $+10 * * * *$ & $+12 * * *$ \\
\hline \multicolumn{5}{|l|}{ Abstinence, underage girls } \\
\hline 2004 & 32 & 25 & 24 & 26 \\
\hline 2006 & 41 & 36 & 38 & 36 \\
\hline Change between 2004-2006 & $+9 * * *$ & $+11 * * *$ & $+14 * * * *$ & $+10 * * *$ \\
\hline
\end{tabular}

$* * * \mathrm{p}<.001 ; * * \mathrm{p}<.01 ; * \mathrm{p}<.05 ; \mathrm{ns}=$ non-significant

did females, at least at baseline. Also the time of purchase seems to have had some bearing on the success rate: more purchases succeeded between 4:00 p.m. and 6:00 p.m., which is the busiest time of the day, than after 6:0o p.m.

Data from the School Health Promotion study (a continuing data-gathering instrument for monitoring the health of adolescents, co-ordinated by the National Institute for Health and Welfare together with municipalities) on ease of buying alcohol from commercial venues confirmed the results of the purchase trial (Table I). The percentage of I4-I7-year-olds who thought it was difficult for people of their own age to buy a bottle of beer or cider in a local store increased in a statistically significant way in both of the intervention areas as well as in their comparisons during the PAKKA inter- vention years of 2004-2006 (Holmila, Karlsson, \& Warpenius, 20I0). Also abstinence from alcohol increased significantly among underage boys and girls in the four research areas (Table I).

The evaluation results appear to show that the project had intensified the enforcement of the alcohol law concerning commercial availability (shops) of alcohol to minors in both the intervention and the comparison areas (Karlsson et al., 2008). According to population surveys, public attitudes toward underage drinking also became more restrictive, and school-based surveys showed that there was some reduction in the social availability of alcohol for minors both in the intervention and in the comparison areas (Table I). In all of the regions studied, alcohol availability for minors was reduced. As a conclusion it can be said that local coalitions 
can be important tools in reducing alcohol availability among minors.

\section{The licensed premises component}

There was a statistically significant increase in the rate of denial of alcohol service to intoxicated customers in the intervention town of Jyväskylä (Area I) compared to the control area (Table 2) $(\mathrm{OR}=3.7$; $\mathrm{p}=.04)$. The biggest increase in refusal rates was in the suburban bars in the intervention town. The program was successful in changing the serving practices of young servers in the intervention town. They refused to sell alcohol to an apparently intoxicated customer more often in the post-intervention test than before the PAKKA program. RBS training alone did not seem to cause the change in the refusal rates.

The policy measures were supported by campaigns to create and reproduce social norms and values for alcohol service and marketing. Information campaigns are important in order to achieve social acceptance for the control action. All in all, our results show that a community prevention project that applies evidence-based methods in systematic ways can be effective in increasing the control of service to intoxicated patrons in bars and pubs. However, our findings show that intoxication is seen as an acceptable condition for customers in nightclubs. Thus, if alcohol policy measures are not applied simultaneously, the self-supervision of restaurants alone would seem to be a weak tool in fighting acute problems related to drunkenness. These findings support the idea that local multicomponent prevention efforts can have an impact on servers' behavior at licensed premises.

\section{Alcohol-related violence and injuries}

Police-reported violence cases in licensed premises in relation to the total number of licensed premises in the area fell in Hämeenlinna (Intervention Area 2), while they grew in the control area (Warpenius \& Holmila, 2008). However, in Intervention Area I (Jyväskylä) the number of violent cases grew, and in the control area it remained unaltered (Table 3). Men's weekend night-time emergency visits per population fell in Intervention Area 2, while in the control they grew slightly among young men (Table 3). In Intervention Area I, in contrast, the number of emergency visits did not reduce for young males.

Table 2

Licensed premise measure in intervention and control areas in 2004 and 2006

\begin{tabular}{lcc}
\hline Measure & $\begin{array}{c}\text { Intervention I } \\
\%\end{array}$ & $\begin{array}{c}\text { Control I } \\
\%\end{array}$ \\
\hline $\begin{array}{l}\text { Refusals to serve an intoxicated } \\
\text { customer }\end{array}$ & \\
$\quad 2004$ & 42 & 36 \\
2006 & $+19 *$ & 27 \\
Change between 2004-2006 & \\
& & -9 \\
\hline
\end{tabular}

$* \mathrm{p}<.05$. The odds ratio for the interaction term was 3.7 and the $\mathrm{p}$-value for the term was .04 .

\section{Discussion}

The evaluation of the PAKKA project was based on several kinds of data and a combination of quantitative outcome evaluation and process evaluation. The evaluation results show that the project intensified the enforcement of the alcohol law concerning commercial availability (i.e., in shops) of alcohol to minors in both the intervention and the comparison areas. Public attitudes toward underage drinking also became more restrictive. There was also a significant increase in the rate of denial of alcohol service to intoxicated customers in the intervention area. It can be concluded that community-based action can reduce underage drinking and availability of alcohol to already intoxicated customers, and thus has a potential to reduce alcohol-related acute harms. 
Table 3

Alcohol-related violence and injuries in intervention and control areas in 2004 and 2007

\begin{tabular}{|c|c|c|c|c|}
\hline Measure & $\begin{array}{c}\text { Intervention I } \\
\% \\
\end{array}$ & $\begin{array}{c}\text { Control I } \\
\% \\
\end{array}$ & $\begin{array}{c}\text { Intervention } 2 \\
\% \\
\end{array}$ & $\begin{array}{c}\text { Control } 2 \\
\% \\
\end{array}$ \\
\hline \multicolumn{5}{|c|}{$\begin{array}{l}\text { Violence in restaurants, cases per } 100 \text { licensed } \\
\text { premises in the area }\end{array}$} \\
\hline 2004 & 97 & 78 & 89 & 105 \\
\hline 2007 & 129 & 75 & 63 & 133 \\
\hline Change between 2004-2007 & +32 & -3 & -26 & +28 \\
\hline \multicolumn{5}{|c|}{$\begin{array}{l}\text { Emergency clinic visits during weekend } \\
\text { nights, visits per 100,000 inhabitants } \\
\text { (15-34-year-old men) }\end{array}$} \\
\hline 2004 & 142 & $\ldots$ & 113 & 113 \\
\hline 2007 & 148 & $\ldots$ & 74 & 121 \\
\hline Change between 2004-2007 & +6 & $\ldots$ & -39 & +8 \\
\hline
\end{tabular}

Results are inconsistent: Control 1 is missing.

However, the outcome evaluation did not show systematic or statistically significant results indicating the effects of the interventions on alcoholrelated violence and injuries, and the results were somewhat contradictory. The number of alcoholrelated injuries and violent incidents in the local police records and emergency unit registers is low, and the follow-up period was relatively short. These are methodological challenges in the outcome evaluation.

The quasi-experimental research setting presumes the intervention to take place only in the intervention sites, while the comparisons are left "untouched." The setting has methodological limitations in assessing the intervention impact in a situation where the local and the national processes overlap, as they did in the case of PAKKA. The positive changes in availability and attitudes can perhaps be interpreted as an outcome of the National Alcohol Program, rather than as outcomes of the local-level action alone. Also, the example provided by the active coalitions in the two intervention sites probably encouraged other localities to take similar action, and thus the wider context of the project may have influenced community processes in a positive way.

But it is important to note that, conversely, the national program may also have been influenced by the local project. The project gave a downto-earth example of practical methods, which are accessible to all local actors, and the co-ordinators gave inspiring talks in different gatherings for local professionals. PAKKA received a lot of attention, both among professionals and among the general public through the media. Presently, PAKKA-type activities are carried out in several new local areas in Finland, supported by a national network.

The frame of reference of injury prevention has been summarized as the three E's: engineering (safety of the environment and the products), enforcement (regulations and their enforcement) and education (influencing attitudes and behavior). Community-based work in prevention offers a forum for combining citizens' action with official policies. Community action can also combine the three E's into one process, affecting both environment, grassroots enforcement of legislation and people's knowledge and attitudes. Preventing acute harms caused by intoxication can save lives and prevent various kinds of physical and social harm. The Finnish PAKKA project demonstrates that regulation of drinking context by community interventions is a feasible method of injury prevention among young people.

\section{References}

Aalto, M., Saksanen, R., \& Laine, P. (2000). Brief intervention for female heavy drinkers in routine general practice: A 3-year randomized, controlled study. Alcoholism: Clinical and Experimental Research, 24, I680-1686.

Ahlström, S., \& Karvonen, S. (2010). Miten nuoret juo- 
vat? [Young people's drinking]. In P. Mäkelä, $\mathrm{H}$. Mustonen, \& C. Tigerstedt (Eds.), Suomi juo. Suomalaisten alkoholinkäyttö ja sen muutokset from 1968 to 2008 [Drinking in Finland: Finnish drinking habits and changes I968-2008] (pp. I29I4I). Helsinki, Finland: THL.

Andersen, J. (2000). Municipalities between the state and the people. In P. Sulkunen, C. Sutton, C. Tigerstedt, \& K. Warpenius (Eds.), Broken spirits: Power and ideas in Nordic alcohol control (NAD Publication 39) (pp. I57-I84). Helsinki, Finland: NAD.

Anderson, P., Laurant, M., Kanner, E., Wensing, M., \& Grol, R. (2004). Engaging general practitioners in the management of hazardous and harmful alcohol consumption: Results of a meta-analysis. Journal of Studies on Alcohol, ${ }_{5}$, I9I-I99.

Babor, T., Caetano, R., Casswell, S., Edwards, G., Giesbrecht, N., Graham, K., . . Rossow, I. (2010). Alcohol: No ordinary commodity. Research and public policy (2nd ed.). New York, U.S.A.: Oxford University Press.

Ballesteros, J., Duffy, J. C., Querejeta, I., Arino, J., \& Gonzalez-Pinto, A. (2004). Efficacy of brief interventions for hazardous drinkers in primary care: Systematic review and metaanalyses. Alcoholism: Clinical and Experimental Research, 28, 608-6I8.

Beich, A., Gannik, D., \& Malterud, K.(2007). Screening and brief intervention for excessive alcohol use: Qualitative interview study of the experiences of general practitioners. BMJ, 325, 870-874.

Bertholet, N., Daeppen, J. B., Wietlisbach, V., Fleming, M., \& Burnand, B. (2005). Reduction of alcohol consumption by brief alcohol intervention in primary care: Systematic review and meta-analysis. Archives of Internal Medicine, 165, 986-995.

Bond, J., \& Macdonald, S. (2009). Causality and causal attribution of alcohol in injuries. In C. J. Cherpitel, G. Borges, N. Giesbrecht, D. Hungeford, M. Pede, V. Poznyak, ... T. Stockwell (Eds.), Alcohol and injuries: Emergency department studies in an international perspective (pp. 27-40). Geneva, Switzerland: World Health Organization.

Borges, G., Macdonald, S., Cherpitel, C., Orozco, R., \& Peden, M. (2009). Variation in alcoholrelated injury by type and cause of injury. In C. J. Cherpitel, G. Borges, N. Giesbrecht, D.
Hungeford, M. Pede, V. Poznyak, .. . T. Stockwell (Eds.), Alcohol and injuries: Emergency department studies in an international perspective (pp. I5-23). Geneva, Switzerland: World Health Organization.

Casswell, S., \& Zhang, J. F. (I997). Access to alcohol from licensed premises during adolescence: A longitudinal study. Addiction, 92, 737745 .

Cherpitel, C. J. (2007). Alcohol and injuries: A review of international emergency room studies since I995. Drug and Alcohol Review, 26, 20I$2 \mathrm{I} 4$.

Cherpitel, C. J., Borges, G., Giesbrecht, N., Hungeford, D., Pede, M., Poznyak, V., . . . Stockwell, T. (Eds.). (2009). Alcohol and injuries: Emergency department studies in an international perspective (pp. 15-23). Geneva, Switzerland: World Health Organization.

Clark, R. (I992). Situational crime prevention: Successful case studies. New York, U.S.A.: Harrow and Heston.

Cuijpers, P. (2002). Effective ingredients of school-based drug prevention programs: A systemic review. Addictive Behaviors, 27, Ioo9IO23.

D’Onorio, G., \& Degutis, C. (2009). Evidencebased emergency department screening and brief intervention for alcohol problems. In C. J. Cherpitel, G. Borges, N. Giesbrecht, D. Hungerford, M. Peden, V. Poznyak, . . . T. Stockwell (Eds.), Alcohol and injuries: Emergency department studies in an international perspective (pp. I6I-I73). Geneva, Switzerland: World Health Organization.

Flay, B. R. (2000). Approaches to substance prevention utilizing school curriculum plus social environment change. Addictive Behaviors, 25, 86I-885.

Foxcroft, D. R., Ireland, D., Lister-Sharp, D. J., Lowe, G., \& Breen, R. (2003). Long-term primary prevention for alcohol misuse in young people: A systematic review. Addiction, 98, 397-4II.

Giesbrecht, N., Ialomiteanu, A., Angling, L., \& Adlaf, E. (2007). Alcohol marketing and retailing: Public opinion and recent policy developments in Canada. Journal of Substance Use, 12, 389404.

Graham, K. (2000). Preventive interventions for on-premise drinking: A promising but underresearched area of prevention. Contemporary 
Drug Problems, 27, 593-668.

Graham, K., Bernards, S., Osgood, D. W., \& Wells, S. (2006). Bad nights or bad bars? Multi-level analysis of environmental predictors of aggression in late-night large-capacity bars and clubs. Addiction, 101, I569-I580.

Graham, K., \& Bernards, S. (2009). Canada: Reports from around the world. In P. Hadfield (Ed.), Nightlife and crime: Social order and governance in international perspective (pp. 237260). New York, U.S.A.: Oxford University Press.

Greenfield, T., Ye, Y., \& Giesbrecht, N. (2007). Views of alcohol control policies in the 2000 National Alcohol Survey: What news for alcohol policy development in the U.S. and its states? Journal of Substance Use, 12, 429444 .

Haddon, W. (I980). Advances in the epidemiology of injuries as a basis for public policy. Public Health Reports, 95, 4II-42I.

Hadfield, P. (Ed.). (2009). Nightlife and crime: Social order and governance in international perspective. New York, U.S.A.: Oxford University Press.

Holder, H. D. (2000). Community prevention of alcohol problems. Addictive Behaviors, 25, 843859 .

Holder, H. D., Gruenewald, P. J., Ponicki, W. R., Treno, A. J., Grube, J. W., \& Saltz, R. F. (2002). Effect of community-based interventions on high-risk drinking and alcohol-related injuries. Journal of the American Medical Association, 284, 234I-2347.

Holmila, M. (Ed.). (I997). Community prevention of alcohol problems. London, U.K.: Macmillan.

Holmila, M., Holder, H., Andréasson, S., Baklien, B., \& Rossow, I. (2008). Roles for researchers in community action projects to prevent alcohol and other drug problems: Methodological choices. Drugs: Education, Prevention and Policy, 15, 410-423.

Holmila, M., Karlsson, T., \& Warpenius, K. (2010). Controlling teenagers' drinking: Effects of a community-based prevention project. Journal of Substance Use, 5, 20I-2I4.

Holmila, M., Mustonen, H., Raitasalo, K., \& Österberg, E. (2009). Public opinion and community-based prevention of alcohol-related harms. Addiction Research \& Theory, 17, 360-37I.
Holmila, M., \& Warpenius, K. (2007). A study on effectiveness of local alcohol policy. Challenges and solutions in PAKKA-project. Drugs: Education, Prevention and Policy, 14, 529-54I.

Holmila, M., \& Warpenius, K. (2009). Finland: Reports from around the world. In P. Hadfield (Ed.), Nightlife and crime: Social order and governance in international perspective (pp. I27-137). New York, U.S.A.: Oxford University Press.

Holmila M., Warpenius K., \& Tigerstedt T. (2008). Visions and means to execute them: Key actors' opinion on local alcohol policy. Nordic Studies on Alcohol and Drugs, 25, 40I-4I8.

Holmila, M., Warpenius, K., Warsell, L., Kesänen, M., \& Tamminen, I. (2009). Paikallinen alkoholipolitiikka Pakka-hankkeen loppuraportti [Local alcohol policy: Final report of the PAKKA project]. Report 5. Helsinki, Finland: National Institute for Health and Welfare (THL).

Homel, R., McIlwain, G., \& Carvolth, R. (200I). Creating safer drinking environments. In N. Heather, T. J. Peters, \& T. Stockwell (Eds.), Handbook of alcohol dependence and alcoholrelated problems (pp. 72I-740). New York, U.S.A.: Wiley.

Huhtanen, P., \& Tigerstedt, T. (2010). Kuinka paljon kärsimme muiden juomisesta [How much do we suffer from the drinking of others]. In P. Mäkelä, H. Mustonen, \& C. Tigerstedt (Eds.), Suomi juo. Suomalaisten alkoholinkäyttö ja sen muutokset from 1968 to 2008 [(Drinking in Finland: Finnish drinking habits and changes I968-2008] (pp. 220-233). Helsinki, Finland: National Institute for Health and Welfare (THL). Impinen, A. (2009). Päihteet ja tapaturmat [Alcohol, drugs and injuries]. In K. Tiirikainen (Ed.), Tapaturmat Suomessa [Injuries in Finland] (pp. 64-68). Helsinki, Finland: Institute for Health and Welfare (THL).

Kaner, E. F., Beyer, F., Dickinson, H. O., Pienaar, E., Campbell, F., Schlesinger, C., ... Burnand, B. (2007). Effectiveness of brief alcohol interventions in primary care populations. Cochrane Database of Systematic Reviews, Issue 2. Art. No.: CDoo4I48. DOI: Io.I002/14651858.CDoo4I48.pub3.

Kantonen, J., Niittynen, K., Mattila, J., KuuselaLehtovuori, P., Manninen-Kauppinen, E., \& Pohjola-Sintonen, S. (2006). Päihtyneet ja päihdeongelmaiset potilaat Peijaksen sairaalan päivystyspoliklinikalla [Intoxicated and addicted patients at the Peijas hospital emergency poli- 
clinic]. Suomen Lääkärilehti, 61, 4923-2497.

Karlsson, T., Raitasalo, K., \& Warpenius K. (2008). "Onks henkkareita?" Ikärjakontrolli alkoholin vähittäismyynnissä [“May I see your ID?” Age limits control in off-premise sales of alcoholic beverages]. Yhteiskuntapolitiikka, 73, I53-16I.

Kivivuori, J. (2008). Rikollisuuden syyt [Criminal behavior]. Jyväskylä, Finland: Gummerus.

Klein, M., \& Quinten, C. (2002). Zur Langzeitentwicklung von kindern stationär behandelter alkoholabhängiger eltern [Long-term development of children of treated alcoholdependent parents]. Sucttherapie, 3, 233-240.

Komro, K. A., \& Toomey T. L. (2002). Strategies to prevent underage drinking. Alcohol Research and Health, 26, 5-I4.

Kraus, L., Baumeister, S. E., Pabst, A., \& Orth, B. (2009). Association of average daily alcohol consumption, binge drinking and alcoholrelated social problems: Results from the German Epidemiological Surveys of Substance Abuse. Alcohol and Alcoholism, 44, 314-320.

Lehti, M., \& Kivivuori, J. (2007). Kuolemaan johtanut väkivalta [Homicide. Crime and criminal justice in Finland]. Publications of the National Research Institute of Legal Policy, 229, I5-47. Helsinki, Finland: Hakapaino.

Lehti, M., Sirén, R., \& Hinkkanen, V. (2007). Muut väkivaltarikokset [Assaults, crime and criminal justice in Finland]. Publications of the National Research Institute of Legal Policy, 229, 49-65. Helsinki, Finland: Hakapaino.

Lounamaa, A., Räback, M., \& Tiirikainen, K. (2009). Tapturmat ja niiden ehkäisy [Injuries and their prevention]. In K. Tiirikainien (Ed.), Tapaturmat Suomessa [Injuries in Finland] (pp. I2-I7). Helsinki, Finland: Institute for Health and Welfare.

Mäkelä, P., Martikainen, P., \& Nihtilä, E. (2005). Temporal variations in deaths related to alcohol intoxication and drinking. International Journal of Epidemiology, 34, 765-77I.

National Research Institute of Legal Policy. (2009). Crime and criminal justice in Finland. Helsinki, Finland: Hakapaino.

Nordlund, S. (2007). The influence of E.U. on alcohol policy in a non-E.U. country. Journal of Substance Use, 12, 405-418.

Nurmi-Lüthje, I., Karjalainen, K., Hinkkurinen, J., Salmio, K., Lundell, L., \& Salminen, M. (2007).
Tapaturmakäyntien tilastointi paljastaa riskiryhmät. Terveydenhuoltoartikkeli [Statistics on visits to injury policlinics conveys riskgroups]. Suomen Lääkärilehti, 62, 3434-3436.

Nurmi-Lüthje. I., Lüthje, P., Karjalainen, K., Salmio, K., Pelkonen, J., Hinkkurinen, J., . . . Virtanen, A. (2008). Väkivallan uhrit aluesairaalan päivystyspoliklinikassa-etenevä tutkimus [Victims of violence in an emergency care policlinic - a study in progress]. Duodecim, 124, I38I-I388.

Peltoniemi, T. (2005). Suomalaisten lasinen lapsuus I994 ja 2004 [The fragile childhood of the Finns]. Tiimi, 2, 4-Io.

Poikolainen, K., Paljärvi, T., \& Mäkelä, P. (2007). Alcohol and the preventive paradox: Serious harms and drinking pattern. Addiction, 102, 57I-578.

Quigley, B. M., Leonard, K. E., \& Collins, R. L. (2003). Characteristics of violent bars and bar patrons. Journal of Studies on Alcohol, 64, 765772.

Ratele, K., Swart, L. A., \& Seedat, M. (2009). South Africa: Reports from around the world. In P. Hadfield (Ed.), Nightlife and crime: Social order and governance in international perspective (pp. 277-292). New York, U.S.A.: Oxford University Press.

Room, R., \& Rossow, I. (200I). The share of violence attributable to drinking. Journal of Substance Use, 6, 218-228.

Runyan, C. W. (1998). Using the Haddon matrix: Introducing the third dimension. Injury Prevention, 4, 302-337.

Salasuo, M., Vuori, E., Piispa, M. \& Hakkarainen, P. (2009). Suomalainen huumekuolema 2007. Poikkitieteellinen tutkimus oikeuslääketieteellisistä kuolinsyyasiakirjoista. [Finnish drug-related deaths: A cross-disciplinary study based on forensic medicine documents]. Reports 43. Helsinki, Finland: National Institute for Health and Welfare (THL).

Seppä, K., \& Aalto, M. (2009). Lyhyet alkoholikyselytestit Suomen riskikuluttajilla. [Brief screening tests among Finnish risk drinkers]. In T. Tammi, M. Aalto, \& A. Koski-Jännes (Eds.), Irti päihdeongelmista [Breaking free from alcohol problems] (pp. Io9-I23). Helsinki, Finland: Edita.

Sirén, R. (2002). Trends in assault: On the relationship between the assault rate and selected social indicators in post-war Finland. Journal of 
Scandinavian Studies in Criminology and Crime

Prevention, 3, 22-49.

Stenius, K. (2000). De nordiska kommunernas roll i alkohol- och drogpolitiken. Traditioner och utmaningar [The role of the Nordic municipality in alcohol and drug policy: Traditions and challenges.] In K. Elmeland (Ed.), Lokalt alcohol-och drogförebyggande arbete $i$ Norden (pp. 47-6o) [Local alcohol and drug prevention in the Nordic countries] (pp. 47-6o). NAD Publication 38. Helsinki, Finland: Hakapaino.

Tiirikainen, K. (Ed.). (2009). Tapaturmat Suomessa. [Injuries in Finland]. Institute for Health and Welfare. Helsinki, Finland: Edita.

Tobler, N. S., Roona, M. R., Ochshorn, P., Marshall, D. G, Streke, A.V., \& Stackpole, K. M. (2000). School-based adolescent drug prevention programs: I998 meta-analysis. Journal of Primary Prevention, 20, 275-336.

Treno A. J., \& Holder H. D. (2004). Prevention at the local level. In N. Heather \& T. Stockwell (Eds.), The essential handbook of treatment and prevention of alcohol problems (pp. 285-297). Chichester, U.K.: Wiley.

Velleman, R. (2002). The children of problem drinking parents: An executive summary. Executive summary series. Executive summary, 70, I-5, London, U.K.: Centre for Research on Drugs and Health Behaviour.

Wagenaar, A. C., Murray, D. M., Gehan, I. P., Wolfson, M., Forster, J. L., Toomey, T. L., .. . Jones-Webb, R. (2000). Communities mobilizing for change on alcohol: Outcomes from a randomized community trial. Journal of Studies on Alcohol, 61, 85-94.

Wallin, E., Norström, T., \& Andréasson, S. (2003). Alcohol prevention targeting licensed premises: A study of effects on violence. Journal of Studies on Alcohol, 64, 270-277.

Wallin, E. (2004). Responsible beverage service: Effects of a community action project. Stockholm, Sweden: Karolinska Institutet.

Wallin, E., \& Gripenberg, J. (2005). Over serving at licensed premises in Stockholm: Effects of a community action program. Journal of Studies on Alcohol, 66, 806-8I4.

Warpenius, K., Holmila, M., \& Mustonen, H. (2OIO). Effects of a community intervention to reduce the serving of alcohol to intoxicated patrons. Addiction, 105, 1032-1040.

Warpenius, K., \& Holmila, M. (2008). Local prevention in licensed premises: Experiences from the Finnish PAKKA-project. In B. Olsoon \& J Törrönen (Eds.), Painting the town red: Pubs, restaurants and young adults' drinking cultures in the Nordic countries (pp. 247-272). NAD Publication 51. Helsinki, Finland: Hakapaino.

Warpenius, K., \& Sutton, C. (2000). The ideal of the alcohol-free society. In P. Sulkunen, C. Sutton, C. Tigerstedt, \& K. Warpenius (Eds.), Broken spirits: Power and ideas in Nordic alcohol control (pp. 45-66). NAD Publication 39. Helsinki, Finland: Hakapaino.

Wiggers, J., Considine, R., Hazell, T., Haile, M., Rees, M., \& Daly, J. (200I). Increasing the practice of health promotion initiatives by licensed premises. Health Education \& Behavior, 28, 33I-340.

Young, D. J., Stockwell, T., Cherpitel, C. J., Ye, Y., Macdonald, S., Borges, G., \& Giesbrecht, N. (2004). Emergency room injury presentations as an indicator of alcohol-related problems in the community: A multilevel analysis of an international study. Journal of Studies on Alcohol, 65, 605-612. 